\title{
Comparative Study on the Implementation of Project Course and Subject Course in Higher Vocational School
}

\author{
Xiaojing Ren \\ Liaoning Petro-chemical College China Liaoning 121001
}

Keywords: Project course; Subject course; Higher vocational class; Contrast

\begin{abstract}
With the continuous improvement of the socialist market economic system, the current employers have put forward higher requirements for the professional and technical level and comprehensive quality of talents. Based on the occupation status of teaching, this paper first introduced the definition of project curriculum and subject curriculum, and then analyzed the characteristics of the project curriculum and subject curriculum, finally expounded the importance of vocational classroom curriculum to realize the curriculum transformation.

With the continuous deepening and improvement of the current project curriculum reform, the major vocational colleges gradually grasp and accept this new classroom teaching mode, and their strong desire for reform also makes the curriculum theory experts feel shocked. In order to further understand the value of project curriculum in Higher Vocational Classroom Teaching and its advantages relative to the subject curriculum, teachers must first understand what is project curriculum and what is discipline curriculum.
\end{abstract}

\section{Part One the Definition of Project Course and Subject Course}

There is not a relatively complete and accurate definition of disciplinary courses and project courses. There are many debates about the two courses in academia. Now, based on several points of view, the following two curriculum models are briefly analyzed.

\section{Subject Course}

Subject course, as its name implies, is a summary of knowledge courses built within a classic subject field. As the target of current project course reform, subject course can be said to have been demonized by many opponents. In fact, the course still occupies an important position in China's modernization courses in Higher Vocational School, which not only continued to transfer students discipline spirit and theoretical knowledge, at the same time for further construction of the subject itself, has an important role to enhance the depth and breadth of disciplines. According to the current industry for the support and criticism of the course, the majority of teaching workers held a negative attitude to the course, they think it is not attached to the curriculum theory system of practice courses, but also think supporters theory course also has a space for one person in higher vocational education, this is a misreading of the course. However, as a traditional teaching model, the continuous integration and transformation of the subject course is also one of the trends of the future higher vocational education.

\section{Project Course}

The project curriculum is the inheritance and development of the task course. It can be simply defined as "the reference point of completing the job assignment, setting up the content through project as a unit, and taking the project activity as the main learning mode". In order to understand the connotation of the project course, we must first recognize what is the project. In the initial creation of the project course teaching method, Berman divided the project into five different categories, which mainly include subjects related projects, subjects related projects, structured projects and open template projects. In the actual teaching process, that the task teaching method is the project teaching method error of some teachers, which will produce a vehicle with the design of a wedding as a project that is actually a part of the graduation design or training, and it is not the real project course. In project teaching, we should not only grasp the overall idea and solution of the project, but also do not combine the objective design with the actual situation of students, which is the connotation and opening point of the project course. 


\section{Part Two Comparison of the Characteristics of the Project Course and the Subject Course}

\section{Comparison of Post Task Correlation Degree}

As everyone knows, in China, the localization of higher education is the combination of education and occupation education, that is to say, talent orientation in higher vocational schools is the occupation personnel also called skilled personnel, this kind of personnel need to have the site control and operation ability, and has strong practicality. According to the traditional teaching mode and current situation, most of the contents of the traditional vocational education courses are not practical. For example, some pharmaceutical professional production may be set to medicine and chemistry, and the accounting profession will set some basic courses in economics, and computer courses will choose some mechanical engineering materials and mechanical design courses, these so-called professional courses in system and undergraduate research universities are similar, but the content is relatively simple. Simplicity does not mean practicality. Some students' understanding of classroom knowledge structure in Higher Vocational School is not deep enough, resulting in their slack mood for the learning of subject courses, which also leads to the imperfect establishment of theoretical knowledge frame system. In addition, because of the difficulty of these knowledge for higher vocational students, they need more time to train their professional skills, and also reduce their enthusiasm and time for theoretical knowledge learning. Although there are many practical contents in the teaching of professional basic courses, it is not satisfactory from the perspective of job relevance. On the one hand is because teachers themselves lack of experience for the future enterprise, engaged in the work of students do not understand, on the other hand, it is reflected in the surface of too much emphasis on linking theory and practice which did not establish a connection in the deep, leading students wrong judgment work difficulty and affecting the formation of the conception of employment.

In contrast, the project course has obvious advantages in the degree of post relevance. From the point of view of the project course, whether it is selected, the project content and project curriculum teaching are closely related to the job tasks, processes and methods of design of parts such as mechanical design professional students can design a teaching mode and parts of the project as far as possible to the actual work experience at the same time which can also be innovative design under the guidance of teachers according to their own ideas, which for strengthening students' occupation attribute to enhance its role and help to have the important level of understanding to industry and comprehension. In the course of the project, through the group practice can effectively improve students' cooperation and explore the art cultivate their ability to explore, to participate in leading group of students that can effectively exercise the leadership qualities to make a positive contribution to the future in the enterprise emerge.

\section{Comparison of the Relationship Between the Course Content and the Post Task}

The course content is the key to decide the teaching effect of the course, in the actual teaching process, with the national requirements for higher vocational colleges occupation skills and practice ability of continuous improvement, at present, most of the colleges and universities have realized the practical course of not less than 50\% hours total requirements, but also to enhance the practical teaching to a certain extent. But the combination of social work into the status of the enterprise hiring needs and students, and the curriculum teaching effect is still lacking, which is mainly embodied in the curriculum setting and the lack of stereotyped job contact leading students still is based on the theory of the practice, and combined with the actual production, so in contact after work only to find and practice content is not consistent with influence the play of their skills.

Project course is different. It must be targeted at the stage of project selection, choosing appropriate projects according to students' interests and teaching objectives and requirements, so there will be no close connection between curriculum content and job tasks. In addition, in the design process of the project, teachers can integrate many theoretical knowledge and practical training contents, further enhance students' cognition of professional skills, which is also helpful for enhancing students' learning ability.

Comparison of Educational Methods

Divide from the view of teaching methods, the traditional curriculum teaching mode and 
teaching theory attention has also added some training courses, through the method of theory with practice to strengthen students' level of basic knowledge to understand and grasp, it will have certain help to enhance students' professional quality, which can not be denied. But along with the competition by the employer is increasing, at present the enterprise for training students' strength is relatively low, students need to adapt to the high intensity of work in a short period of time, it also requires that students in pre-employment skills not only to do more to prepare. In the project teaching, the students through the project practice of knowledge and skills, both completed the occupation planning, aware of the nature and characteristics of the professional skills and techniques, and to get the training, to achieve the transformation of individual employment consciousness, so the project in the method of education courses to make students more easy to accept.

\section{Part Three Importance of Subject Course Transformation Project}

\section{Improving Students' Interest in Learning}

Different from the traditional subject course, project course can be properly selected according to the actual situation of the students' interest in the teaching process, let students choose their familiar or wish to participate in the project itself that can effectively arouse the enthusiasm of students, improve the classroom participation. In addition, the project course is different from traditional training courses, which is very similar to the actual working situation of enterprises, so it is more likely to attract students' attention and further enhance the effect of reinforcement learning.

\section{Embodying the Essence of Vocational Education}

Huang Yanpei, a famous educationist, once said that the basic goals of vocational education can be divided into three stages. The first stage is the stage of personal livelihood, the second stage is the stage of personal service for the society, and the third stage is to increase productivity for the country and even the human society. From the three stages in the US is not difficult to see that the occupation education is the essence of skills and literacy, and the content in the program is fully reflected, the personal social service function is through participation in employment and other activities to achieve with the realistic value and significance to carry out the visible project course.

\section{Helping Students to Set up a Correct Idea of Job Hunting}

The correct concept of job selection can not only help students to obtain high quality employment, but also have important help for the better planning of life and the realization of personal value. Especially under the influence of the current bad social atmosphere of money supremacy, it is important for students to concentrate more on their specialties rather than paying much attention to treatment and money through project teaching.

\section{Conclusion}

In summary, as the traditional teaching mode in higher vocational colleges, the teaching have their own advantages and characteristics, but with the social progress and development, putting forward higher requirements of the employers for talents of practice and operation ability, so that the traditional academic curriculum cannot meet the demand of talent education, must seek the reform and transformation of new. In this paper, through comparison of project course and subject course, analyzing the advantages of the project course and prone to problems in the curriculum teaching, and analyzes the important role of the curricula transformation project course, also hope to be able to lay a good foundation for the smooth development of teaching activities in Higher Vocational School.

\section{Acknowledgement}

The thesis is one of the research findings of "Empirical Study of Project-based Teaching to Improve the Quality of Classroom Teaching in Higher Vocational College" (Project number: 16YB019) which is a general project of "13th Five-Year" Higher Education Scientific Research Projects of the 
2016 Chinese Higher Education Association

\section{Reference}

[1] Zhongli Liu. Research on the construction of vocational career education curriculum in Higher Vocational School Based on project course[D].Shanghai Normal University,2016.

[2] Wengen Zhou. Research on the theory and development technology of project course[J].Vocational and Technical Education in China,2014,(15):79-84.

[3] Youli Wu. Study on the teaching design of project course guided by the work process[D].Zhejiang University of Technology,2011.

[4] Yanni Feng. Research on project activity design in vocational education project course[D].East China Normal University,2010.

[5] Xiuguo Zhang. The study of the vocational education project course based on the working process[D].Hebei Normal University,2010.

[6] Xinkai Zhao. The practice and research of the project course design of the work process oriented project[D].East China Normal University,2009. 